\title{
Pembentukan Peraturan Desa di Desa Telang dan Gili Timur - Bangkalan
}

\author{
Encik Muhammad Fauzan dan Uswatun Hasanah \\ Fakultas Hukum Universitas Trunojoyo Madura \\ Email: encik.fauzan@trunojoyo.ac.id \\ DOI: https://doi.org/10.21107/pangabdhi.v5i2.6111
}

Artikel Diterima : 12 Agustus 2019/ Revisi : 7 September 2019/Terbit : 19 Oktober 2019

\begin{abstract}
Abstrak
Pembentukan Peraturan Desa bagi pemerintahan desa sangat menyulitkan karena keterbatasan sumber daya manusia khususnya pada faktor pendidikan yang rendah. Sementara pada Undang-Undang Nomor 6 Tahun 2014 tentang Desa, pemerintahan desa dapat membentuk peraturan desa untuk melaksanakan berbagai kebijakan Kepala Desa. Berdasarkan hal ini maka tujuan dari pelaksanaan pengabdian ini adalah untuk meningkatkan kemampuan perangkat desa dalam menyusun peraturan desa. Maka untuk meningkatkan dalam merancang peraturan ini maka digunakan metode partisipasi aktif dan pendampingan kepada perangkat desa dan anggota BPD. Partisipasi aktif adalah kegiatan pelatihan yang mengutamakan keaktifan peserta mempraktekkan dalam merancang peraturan desa. Sementara pendampingan dimaksudkan untuk memberikan masukan dan arahan ketika perangkat desa maupun BPD dalam merancang peraturan desa. Hasil dari kegiatan ini adalah pemerintahan desa pada kedua desa tersebut dapat menyusun rancangan peraturan desa terkait pembentukan Badan Usaha Milik Desa.
\end{abstract}

Kata Kunci: pembentukan, peraturan desa, pendampingan, pelatihan, BUMDes.

\begin{abstract}
Making village regulation for village government is very difficult because of limited human resources, especially in the case of low education. While in Law Number 6 of 2014 concerning Villages, village government can form village regulations to implement various Village Head policies. Based on this, the purpose of the implementation of this service is to improve the ability of village officials in preparing village regulations. So to improve in designing this regulation, the method of active participation and assistance to village officials and BPD members is used. Active participation is a training activity that prioritizes the activeness of the participants in practicing in designing village regulations. While assistance is intended to provide input and direction when village officials and BPD in making village regulations. The result of this activity is that the village government in the two villages can draft a village regulation related to the establishment of a Village-Owned Enterprise.
\end{abstract}

Keywords: making, village regulation, assistance, training, Village-Owned Enterprise.

\section{PENDAHULUAN}

Undang-undang Nomor 6 Tahun 2014 tentang Desa dan Undang-Undang Nomor 23 Tahun 2014 tentang Pemerintahan Daerah masih perlu untuk disosiliasikan kepada masyarakat luas. Sosialisasi bukan hanya menyampaikan adanya undangundang baru akan tetapi memberikan pemahaman bagaimana melaksanakan undang-undang tersebut kepada pemegang peran yaitu pemerintahan daerah dan pemerintahan desa. Membaca perundang-undangan saja tidaklah cukup dalam menerapkan apa kehendak dari amanah undang-undang tersebut. Oleh karena itu, perlu pendampingan bagaimana mewujudkan isi dari undang-undang tersebut yaitu khususnya terhadap Undang-Undang Nomor 6 Tahun 2014.

Keberadaan Desa dengan adanya UU Desa ini menunjukkan komitmen pemerintah terhadap pembangunan di Desa. Keberadaan UU Desa juga telah memberikan perlindungan dan pengakuan terhadap masyarakat hukum adat dan hak-hak tradisionalnya melalui sebuah sistem penyelenggaraan Pemerintahan Desa. Oleh karena itu, penyelenggaraan pemerintahan desa memerlukan tata kelola pemerintahan yang baik yang dimulai dari perencanaan sampai pelaksanaan pembangunan dan evaluasi sehingga terwujudnya kesejahteraan masyarakat desa.

Pelaksanaan pemerintahan desa masih memerlukan pendampingan agar tujuan dari penyelenggaraan pemerintahan desa sesuai dengan amanah undang-undang. Berdasarkan hal ini, perlu menyusun panduan penyelenggaraan pemerintahan desa sebagai bentuk sosialisasi dan 
pemecah masalah dalam penyelenggaraan pemerintahan desa. Hal ini dikarena bahwa permasalahan-permasalahan pada desa akan semakin kompleks dengan perkembangan pembangunan nasional dan globalisasi yang tidak bisa kita hindari.

Desa Telang dan Desa Gili Timur Kecamatan Kamal Kabupaten Bangkalan merupakan desa yang mempunyai masalah hukum dalam pembentukan peraturan desa. Kedua desa ini belum memahami betul bagaimana untuk membentuk peraturan desa yang dapat meningkatkankan kesejahteraan masyarakat pada desa tersebut. Peraturan Desa yang saat ini dbutuhkan oleh kedua desa tersebut adalah peraturan desa terkait pembentukan Badan Usaha Milik Desa yang memang sangat diperlukan bagi kedua desa tersebut. Permasalahan yang dihadapi kedua desa ini adalah

a. Kemampuan Pemerintah Desa menyusun rancangan Perdes mengenai BUMDes termasuk menyusun anggaran dasar maupun anggaran rumah tangga dan struktur organisasi masih rendah

b. Tingkat kesadaran masyarakat tentang keberadaan BUMDes masih rendah padahal BUMDes merupkan unit ekonomi multi sektor yang pengelolaannya dilakukan oleh pemerintah desa dan masyarakat untuk kepentingan masyarakat desa.

c. Tidak adanya dana awal untuk membentuk BUMDes menjadi kendala dalam pendirian BUMDes.

Permasalahan yang dihadapi kedua desa tersebut maka perlu untuk dilakukan pendampingan untuk menyelesaikan hal tersebut.

\section{METODE}

Pelaksanaan penyelesaian pembentukan peraturan desa ini dilaksanakan di Desa Telang dan Gili Timur Kecamatan Kamal Kabupaten Bangkalan. Kedua desa ini mengalami permasalahan hukum dalam pembentukan peraturan desa khususnya terkait dengan pembentukan Badan Usaha Milik Desa (BUMDes). Terkait hal ini, maka untuk menyelesaikan masalah hukum dalam pembentukan peraturan desa pada dua desa ini dilakukan dengan menggunakan metode pendampingan, pelatihan dan focus group discussion (FGD).

Pendampingan merupakan kegiatan ke mendatangi ke kedua desa tersebut untuk melihat secara langsung dan membetulkan dalam pembentukan peraturan desa sehingga menghasilkan peraturan desa yang baik sesuai dengan peraturan perundang-undangan. Metode pelatihan digunakan untuk meningkatkan sumber daya manusia pada kedua desa tersebut sehingga dapat secara mandiri membentuk peraturan desa. Dan Metode FGD digunakan untuk sebagai fourm diskusi terbatas untuk menyelesaikan masalahmasalah khusus atau masalah lain terkait pembentukan peraturan desa tentang Badan Usaha Milik Desa. Dengan FGD ini diharapkan pesoalan yang muncul segera dapat dicarikan solusi sehingga proses pembentukan peraturan tersebtu dapat berjalan dengan baik.

Selain itu, dalam melengkapi ketiga metode tersebut juga disusun buku panduan penyelenggaraan pemerintahan desa yang meliputi pembentukan peraturan desa dan pembentukan Badan Usaha Milik Desa. Panduan ini diharapkan dapat digunakan ketiga proses pendampingan, pelatihan dan FGD telah berakhir.

\section{HASIL DAN PEMBAHASAN}

Pelaksanaan pengabdian untuk menyelesaikan masalah hukum yang dihadapi oleh kedua desa ini menjadi hal penting karena melihat kondisi kedua desa tersebut memang membutuhkan pendampingan dan pelatihan dalam penyusunan peraturan desa. Tujuan pendampingan dan pelatihan penyusunan peraturan desa ini untuk membantu pemerintahan desa tersebut dalam menggali potensi desa seperti pembentukan BUMDes melalui peraturan desa.

BUMDes merupakan lembaga atu institusi yang bersifat ekonomis, yang didirikan, dimiliki dan dikelola oleh pemerintah desa. Keberadaan BUMDes dimaksudkan sebagai upaya memberikan pelayanan prima terhadap kebutuhan yang menyangkut hajat hidup orang banyak sekaligus menanggulangi masalah kemiskinan dan meningkatkan taraf hidup masyarakat di desa. Selain itu, BUMDes juga dimaksudkan untuk meningkatkan pendapatan asli desa sehingga memperkuat kemandirian desa terutama di bidang keuangan. Dasar hukum pendirian BUMDes adalah UU Nomor 6 Tahun 2014 tentang Desa, di dalamnya menjelaskan bahwa desa dapat mendirikan BUMDes yang dikelola dengan semangat kekeluargaan dan gotongroyong melalui musyawarah desa. BUMDes dapat menjalankan usaha di bidang ekonomi, dan/atau pelayanan umum dimana manfaatnya adalah 
semata-mata tidak lain untuk pengembangan usaha, pembangunan, pemberdayaan, pemberian bantuan melalui hibah dan bantuan sosial bagi desa sehingga kesejahteraan masayarakat desa dapat terwujudkan.

Bentuk badan hukum badan usaha milik Nasional/Daerah pada umunya adalah perseroan terbatas contohnya PT BNI, PT PLN, PT KAI, PT Pos Indonesia, PT Bank Daerah, dll. Sangat jarang BUMN/D yang masih berbentuk perum, karena dianggap tidak sesuai dengan sistem persaingan usaha di era globalisasi dan swastanisasi (privatisasi), jarang pula yang berbentuk CV karena lebih mengarah kepada bentuk perusahaan perorangan dan keluaraga/kelompok yang tidak cocok dengan usaha milik pemerintah yang harus mengedepankan kepentingan publik.

Mempertimbangkan kecenderungan perkembangan tersebut serta visi dan misi yang harus diemban maka BUMDes sebaiknya berbentuk PT. sedangkan pengelola BUMDes Pengelola BUMDes terdiri dari dewan komisaris dan dewan komisaris. Pengelola BUMDes dipilih dan ditetapkan melalui rapat pemegang saham dan disetujui oleh pemdes dan BPD. Prose pemilihan diatur dengan tata tertib yang disussun berdsarkan statute, AD/ART, Perdes terkait, dan akta notaries pendidikan BUMDes.

Adapun yang menjadi prinsip dasar pertimbangan pendirian BUMDes adalah sabagai berikut:

a. Pemilihan jenis BUMDes sebaiknya mempertimbangkan kebutuhan dan potensi ekonomi yang ada di desa. Secara umum jenis-jenis kebutuhan masyarakat desa di bidang ekonomi adalah Kebutuhan kesehatan fisik dan mental. Sebagai contoh, kebutuhan peningkatan gizi menuntut adanya pendapatan tetap yang mencukupi untuk membeli bahan pangan dengan gizi standart. Biaya pendidikan anak. Sebagai contoh banyaknya anak desa yang putus sekolah untuk sebagian disebabkan oleh faktor keuangan yang pad gilirannya menjadikan tingkat pemahamandan pengetahuan warga desa rendah sehingga pengelolaan asset-aset desa tidak optimal.

b. Usaha-usaha produktif yang dimiliki warga banyak tergantung kepada pihak luar terutama dalam pematokan harga dasar dan wilayah jangkauan pemasaran, selain karena akses yang kurang. Hal ini juga diakibatkan oleh bentuk pengelolaan lembaga usaha yang tidak profesional. c. Akumulasi modal yang berputar di desa masih sangat jarang ditangani secara kolektif dalam bentuk institusi usaha. Sedangkan jenis-jenis potensi bidang ekonomi yang secara umum dimiliki desa antara lain:

d. Adanya permintaan bersama dan sejenis dari kebutuhan warga (bahan, pangan, alat pertanian, kebutuhan modal dll).

e. Adanya sumberdaya bersama (asset desa, modal individu, semangat gotongroyong, dll).

f. Adanya kepentingan bersama

Potensi desa yang dimaksud di atas harus dikelola sepenuhnya oleh masyarakat desa sebagai wadah aktivitas perekonomi masyarakat yang dibentuk berdasarkan kebutuhan dan guna memperkuat pertumbuhan dan pemerataan ekonomi desa. Sebagaimana potensi ekonomi desa Telang dan Gili Timur yang perlu digali adalah masih adanya lahan tidur, lahan tidak efektif karena ditinggal pemiliknya menjadi TKI, banyaknya jumlah pengangguran, adanya rentenir, semuanya itu merupakan potensi yang perlu dicari jalan keluarnya. Oleh karena itu, keberadaan BUMDes menjadi penting sebagai wadah pengembangan potensi desa untuk meningkatkan pendapatan masyarakat. Beberapa bidang usaha yang mungkin dapat dijalankan oleh BUMDes yaitu:

a. bidang Pertanian:

b. bidang peternakan;

c. bidang simpan pinjam;

d. bidang pengelolaan sampah;

e. bidang home industry; dan

f. bidang pasar.

Dalam hal perencanaan dan pembentukannya, BUMDes dibangun atas prakarsa (inisiasi masyarakat) serta mendasarkan pada prinsipprinsip kooperatirf, partisipatif dan emansipatif. Namun di sisi lain, kesadaran masyarakat atas keberadaan BUMDes masih rendah sehingga hal itu perlu dilakukan sosialisasi. Pemerintahan Desa yang terdiri dari Pemerintah Desa dan Badan Permusyawaratan Desa (BPD) berwenang untuk mengatur dan mengurus kepentingan masyarakat setempat, membina kehidupan masyarakat desa, dan mengkoordinasikan pembangunan desa secara partisipatif. Di samping itu, Pemerintah Desa juga berwenang untuk mengajukan rancangan Peraturan Desa (Raperdes) mengenai BUMDes untuk dibahas bersama BPD. Sampai saat ini Desa Telang dan Desa Gili Timur belum didirikan BUMDes karena persyaratan yang harus 
dipenuhi yaitu penyusunan Peraturan Desa, hal ini disebabkan pemerintah desa berlatar belakang bukan sarjana hukum sehingga keterbatasan ini memerlukan pemecahan tersendiri. Di sisi lain, kesempatan memperoleh pelatihan dalam penyusunan Peraturan Desa mengenai BUMDes sangat terbatas, sehingga Pemerintah Desa belum bisa melaksanakan kewenangannya yang berupa pengajuan Rancangan Perdes tentang BUMDes tersebut. Untuk itu, pemerintah Desa perlu diberi bekal tentang penyusunan Perdes, khususnya teknik perancangan Perdes sebagai produk dari kewenangan yang dimilikinya sebagai landasan hukum dalam pembentukan BUMDes.

\section{Pendampingan Pembentukan Perdes}

Desa Telang dan Desa Gili TImur sampai saat ini belum mempunyai peraturan desa. Hal ini menunjukkan bahwa kedua desa tersebut belum mempunyai pengalaman dalam membentuk peraturan desa. Kegiatan pemdampingan ini ditujukan kepada perangkat desa dan anggota BPD agar mereka mempunyai rasa percaya diri dalam membentuk peraturan desa khususnya tentang BUMDes. Pendampingan ini dilakukan karena tingkat kesadaran perangkat desa dan masyarakat desa tentang keberadaan BUMDes masih rendah padahal BUMDes merupkan unit ekonomi multi sektor yang pengelolaannya dilakukan oleh pemerintah desa dan masyarakat untuk kepentingan masyarakat desa.

Selain itu, kemampuan Pemerintah Desa menyusun rancangan Perdes mengenai BUMDes termasuk menyusun anggaran dasar maupun anggaran rumah tangga dan struktur organisasi masih rendah. Pemerintah Desa juga tidak adanya dana awal untuk membentuk BUMDes menjadi kendala dalam pendirian BUMDes. Padahal adanya sumberdaya alam yang dimiliki oleh desa, hal ini sangat rawan sekali terjadi intervensi modal dan pasar di pedesaan. Kehadiran BUMDes ini sebagai perusahaan desa diharapkan mampu menggerakkan dinamika ekonomi desa dan menjadi penangkal bagi kekuatan korporasi asing dan nasional. .Di samping itu, BUMDes juga diharapkan dapat menciptakan lapangan pekerjaan baru, menghasilkan barang dan jasa substitusi desa, meningkatkan perdagangan antarpemerintah desa.

Dari Pendampingan ini maka dihasilkan suatu draft peraturan desa tentang pembentukan
BUMDes dengan melihat permasalahan yang dihadapi oleh kedua desa tersebut.

\section{Pelatihan Pembentukan Peratruran Desa}

Pelatihan pembetukan peraturan desa diikuti oleh perwakilan perangkat desa dan anggota BPD. Dalam pelatihan ini diberikan dua materi utama yaitu tentang teknik penyusunan peratuan desa dan pemahaman pengelolaan BUMDes. Materi pembentukan peraturan desa diawali dengan memberikan pemahaman terhadap jenis peraturan dalam pemerintahan desa. Jenis peraturan di Desa terdiri atas Peraturan Desa, peraturan bersama Kepala Desa, dan peraturan Kepala Desa.

Terkait dengan peraturan desa maka Rancangan Peraturan Desa wajib dikonsultasikan kepada masyarakat Desa. Masyarakat Desa berhak memberikan masukan terhadap Rancangan Peraturan Desa. Peraturan Desa dan peraturan Kepala Desa diundangkan dalam Lembaran Desa dan Berita Desa oleh sekretaris Desa. Dalam pelaksanaan Peraturan Desa, Kepala Desa menetapkan Peraturan Kepala Desa sebagai aturan pelaksanaannya.

Selain materi diatas juga diberikan materi terkait tata kelola BUMDes. BUMDes merupakan lembaga atu institusi yang bersifat ekonomis, yang didirikan, dimiliki dan dikelola oleh pemerintah desa. Keberadaan BUMDes dimaksudkan sebagai upaya memberikan pelayanan prima terhadap kebutuhan yang menyangkut hajat hidup orang banyak sekaligus menanggulangi masalah kemiskinan dan meningkatkan taraf hidup masyarakat di desa. Selain itu, BUMDes juga dimaksudkan untuk meningkatkan pendapatan asli desa sehingga memperkuat kemandirian desa terutama di bidang keuangan.

Dasar hukum pendirian BUMDes adalah UU NO. 6 tahun 2014 tentang Desa, di dalmnya menjelaskan bahwa desa dapat mendirikan BUMDes yang dikelola dengan semangat kekeluargaan dan gotongroyong melalui musyawarah desa. BUMDes dapat menjalankan usaha di bidang ekonomi, dan/atau pelayanan umum dimana manfaatnya adalah semata-mata tidak lain untuk pengembangan usaha, pembangunan, pemberdayaan, pemberian bantuan melalui hibah dan bantuan sosial bagi desa sehingga kesejahteraan masayarakat desa dapat terwujudkan. 


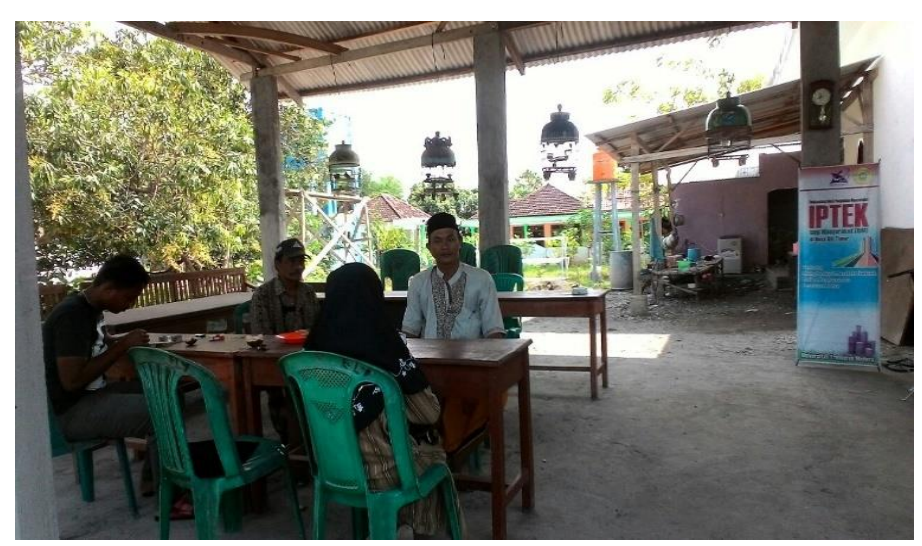

Gambar 1. Pendampingan awal untuk menggali permasalahan dalam pembentukan peraturan desa tentang BUMDes di Desa Gili Timur (Sumber: Foto dari Penulis tahun 2016)

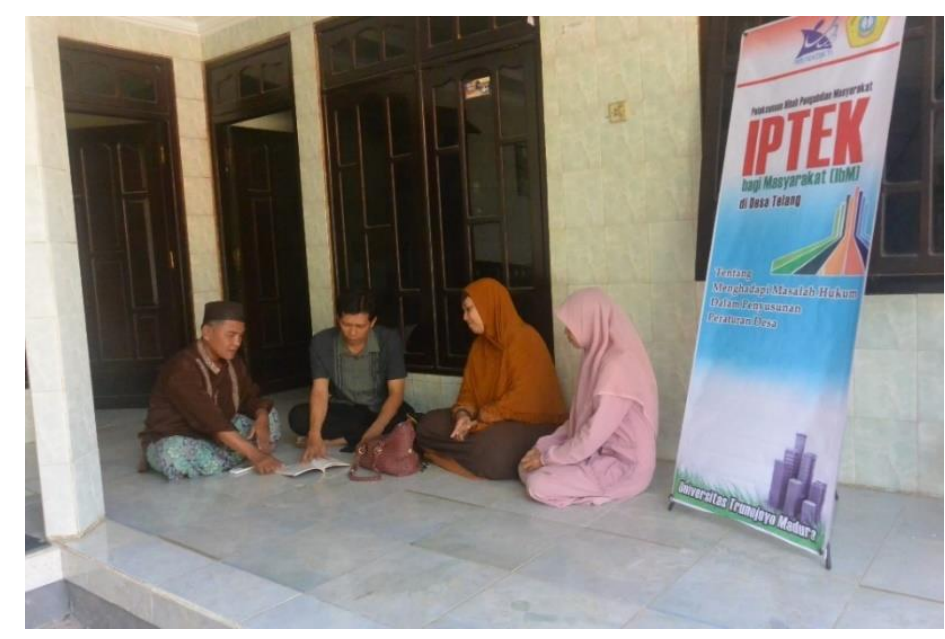

Gambar 2. Pendampingan awal untuk menggali permasalahan dalam pembentukan peraturan desa tentang BUMDes di Desa Telang (Sumber: Foto dari Penulis tahun 2016

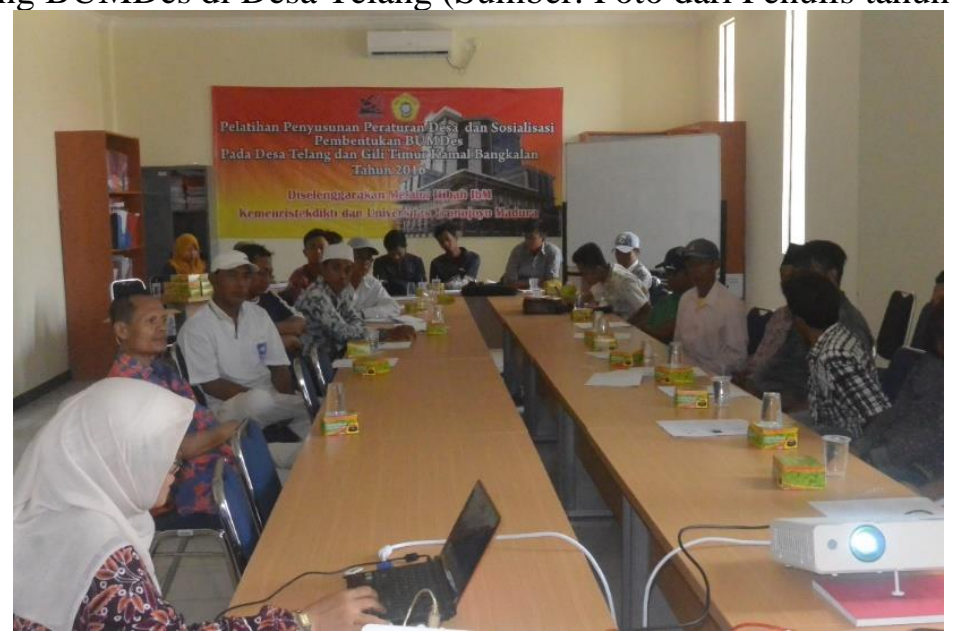

Gambar 3. Pelatihan Penyusunan Peraturan Desa (Sumber: Foto dari Penulis (2016) 
Focus Group Discussion Pembentukan Peraturan Desa.

FGD dilakukan untuk mendalami dari hasil pelatihan sebelumnya. Tujuan dari FGD ini adalah untuk lebih focus dalam terhadap persolan atau kendala dalam menyusun peraturan maupun pengelolaan BUMDes. Kegiatan FGD hanya melibatkan beberapa orang yang terkait dalam pembentukan peraturan desa dan orang-orang yang akan terlibat dalam pengelolaan BUMDes. Dengan FGD akan lebih mendalam dari materi pelatihan sehingga muncul solusi atau dapat memecahkan persoalan-persoalan atau kendalakendala dalam menyusun peraturan desa.

Diskusi dalam FGD ini ternyata lebih banyak membahas tentang usaha apa yang akan dikelola BUMDes. Oleh karena itu, tahapan untuk identifikasi potensi desa itu sangat penting untuk menghasilkan jenis usaha yang cocok bagi BUMDes yang akan dibentuk. Setelah tahapan identifikasi maka yang didiskusikan dalam FGD juga terkait tahapan pembuatan studi kelayakan dan tahapan penentuan bentuk institusi dalam BUMDes.

\section{KESIMPULAN}

Berdasarkan uraian diatas bahwa untuk menyelesaikan masalah hukum dalam pembentukan peraturan desa dapat dilakukan dengan tiga kegiatan yaitu pendampingan, pelatihan dan focus group discussion. Selain itu, untuk menunjuang ketiga kegiatan ini, juga terdapat buku panduan penyelenggaraan pemerintahan desa sebagai buku saku bagi perangkat desa, BPD dan pengelola BUMDes. Untuk itu perlu pemerintah daerah melakukan bimbingan teknis dalam pembentukan peraturan desa dan pembentukan BUMDes.

\section{UCAPAN TERIMA KASIH}

Kami mengucapan terima kasih kepada Kemenristekdikti Republik Indonesia melalui DRPM yang telah mendanai program pengabdian kepada masyarakat ini melalui skema Ipteks bagi Masyarakat (IbM) ini pada tahun 2016.

\section{DAFTAR PUSTAKA}

Mubyarto. 1984. Pembangunan Pedesaan. P3PK UGM. Yogyakarta.

Nurcholis, H. 2011. Pertumbuhan dan Penyelenggaraan Pemeritahan Desa. Erlangga. Jakarta.

Silahuddin, M. 2015. Kewenangan Desa dan Regulasi Desa. Kementerian Desa Pembangunan Daerah Tertinggal dan Transmigrasi Republik Indonesia JakartaIndonesia.

Sukriono, D. 2010. Pembaharuan Hukum Pemerintah Desa Politik Hukum Pemerintah Desa di Indonesia. Malang: Setara Press kerjasama dengan Pusat Kajian Konstitusi Universitas Kanjuruhan.

Widjaja, H.A.W. 2002. Pemerintahan Desal Marga Berdasarkan UndangUndang Nomor 22 Tahun 1999 tentang Pemeritahan Daerah. PT. Raja Grafindo Persada, Jakarta. 